\title{
Conceptualising the Life Expectancy of House Components in Malaysia
}

\author{
Norfarahayu Kariya $^{1}$, Nor Haslinda Abas ${ }^{1, *}$, Hairuddin Mohammad ${ }^{2}$, and Siti Khalijah \\ Yaman $^{1}$ \\ ${ }^{1}$ Department of Building and Construction Engineering, Faculty of Civil and Environmental \\ Engineering, Universiti Tun Hussein Onn Malaysia, 86400 Parit Raja, Batu Pahat, Johor, Malaysia \\ ${ }^{2}$ Faculty of Architecture, Planning, \& Survey, Universiti Teknologi Mara, 40450 Shah Alam, \\ Selangor, Malaysia
}

\begin{abstract}
House maintenance is crucial to ensure the longevity of house components, in the same time retaining their functionality. Unfortunately, house owners are usually caught off-guarded, especially when house components were already deteriorated without warning. Adding salt to the wound, major house maintenance and rectification generally occur after defect liability period in which the costs incurred are not covered by the developer. The pertaining issue of lack prevention measures towards house components at certain point of time is prevalent. Since there is no established pre-rectification guideline that is able to assist house owners to proactively self-evaluate their house components from time to time, the said problem stays firm. Here, as far as maintenance's guideline is concerned, knowledge gap in terms of life expectancy (LE) of generic house components is well observed. Therefore, the authors embarked on research exploration through literatures on identifying the factors leading to LE for house components and further suggested average LE for generic house components. However, the authors limit the paper within the initial process of research exploration to understand the central phenomenon of this study, which only governed the process of reviewing literatures. In a nutshell, the authors posit that LE was worth explored by embedding a multi-layered thematic analysis which comprised of several interconnected themes between house components and life expectancy of house component. Finally, the authors are optimist that the initial outcome from the literature reviews is paramount for subsequent phases, for instance validation and data gathering phases.
\end{abstract}

\section{Introduction}

The average house price in Malaysia have continued to rise from RM138,712 in 2000 to RM317,768 in 2015 [1]. Despite the increment of house price, many house buyers are still looking for new house, where it has become the biggest investment for them. There are several common considerations that will influence the potential house buyers to finalize their purchase decisions like house price, location of the house, the developer's track record,

*Corresponding author: nhaslin@uthm.edu.my 
future capital gain, and etc. However, those considerations frequently shadowed the important latent factor, which is building maintenance. Building (particularly house) maintenance is crucial when the house owners need to extend the functionality and longevity of the house [2]. Additionally, due to the augmentation of house and material price every year [3], periodic and pre-maintenance actions by owners are seen to be extremely important. Unfortunately, most house owners are caught off guarded towards the need of maintenance until in the very later stage when deteriorated house components were evident. Since reparation in those stage is generally incurring much larger cost [2,4], the particular situation is able to prolong from bad to worst especially for the ones with limited funds. Adding salt to the wound, major house maintenance and rectification often occurred after defect liability period, where it is the responsibility of the owners to inspect and rectify the defects. Failure to rectify at the specified time may cause injury to the owners and damage to the property [5].

Seeing the above concerning issue, the authors embarked on conceptualising the overall research problem and found out that there is no proper pre-rectification guideline or standard that can assist house owners to self-evaluate their house components from time to time. Thus, preliminary preparations are needed to preserve the components from further and critical damages, and to avoid infectious damages towards other part of components [6]. As house maintenance is important, having initial information for house owners regarding the life expectancy of each house components is paramount. Apart from providing knowledge per se, the move could provide sufficient buffer period for house owner towards future maintenance, and lest paving for establishment of proper guideline regarding the matter. In order to give a fair example from other developed nation, in the UK, there are established guidelines for house owners regarding to maintenance from the pre-stages of construction until occupancy period [7,8]. Features in the guideline include the life expectancy of house components, where a proper study towards it has been conducted on a larger scale [9]. However, these guidelines cannot be directly applied in Malaysia due to several differences including regions, weather and environment; in which the differences could possibly affect the life expectancy of each house components. Realizing the importance of having a preliminary knowledge of house components' life expectancy, the authors therefore intend to determine an appropriate approach of conceptualising the factors which possibly affect the life expectancy of house components and their associated average of life expectancy based on the Malaysia's environment before further establishment are conducted.

\section{Malaysia's housing environment}

Malaysia is made up of thirteen states and three federal territories across the South China Sea namely; Peninsular Malaysia and East Malaysia with a total landmass of 328,543 square kilometres [10]. Peninsular Malaysia consists of eleven states and two federal territories which is categorised by region namely; Northern region (i.e Perlis, Kedah, Penang, Perak), East Coast region (i.e. Kelantan, Terengganu, Pahang), Central region (i.e. Selangor, federal territories of Kuala Lumpur and Putrajaya) and Southern region (i.e. Negeri Sembilan, Melaka, Johor). While East Malaysia consists of the Malaysian state of Sabah, Sarawak, and the Federal Territory of Labuan. In 2016, total population of Malaysia is estimated at 31.7 million of persons, comprises of 16.4 million of males and 15.3 million of females. Selangor recorded the highest percentage of population in 2016 followed by Sabah and Johor. While Wilayah Persekutuan Labuan and Wilayah Persekutuan Putrajaya are the smallest percentage of population [11]. Located near the equator, Malaysia's climate is categorised as equatorial, being hot and humid throughout the year [12]. 
The growth of Malaysian construction industry has been increased from year to year and at the same time has contributed to the strengthening of economic development of the country. Generally contributing a moderate growth until 2008, fortunately the contribution of the construction industry is on the rise from 2009 until recently [13]. This phenomenon has enrolled Malaysia in line with other developed countries such as United Kingdom, United States of America, Australia and many more [14]. Apart, recorded value of total construction works done in 2015 is over RM30 million, comprises of residential buildings, non-residential buildings, civil engineering and special trade sectors [13]. Among these sector, civil engineering sector is accountable as a strong contender by $33.9 \%$, followed by non-residential buildings $(32.3 \%)$, residential buildings $(29.1 \%)$ and special trade $(4.8 \%)$ [13].

From micro perspective, through the statistics released by the Ministry of Housing and Local Government (KPKT) and the Department of Valuation and Property Services (JPPH), it was reported that the residential sector continued to lead the property market, accounting for 246,225 (2013) and 247,251 (2014) of units, and Selangor, Kuala Lumpur, and Johor are the highest states with new launches of housing developments in the particular periods. However, few months after the implementation of Goods and Services Tax (GST) in early 2015, this sector showed moderate growth due to various reactions amongst construction players including manufacturers and suppliers, and house buyers [15]. Furthermore, general property prices have increased every year since 2000 (RM138,712) until third quarter of 2015 (RM317,768) [13]. However, the average house price in Malaysia has been slightly reduced to RM315, 287 at the end of fourth quarter 2015. Accordingly, reported house price changes for terraced house is $5.4 \%$ at RM278,826, high-rise residential property is $6 \%$ at RM296,826, detached house is $4.1 \%$ at RM524,260, and semi-detached house is $6 \%$ at RM469,823 [13]. Since housing sector becomes one of the main focus of the national agenda (i.e. providing affordable houses for the Rakyat), the Government has created various housing programs, schemes, and incentives to help people in various categories of household income, to be able to own a house.

Thus, for the final leg of becoming an advanced country by 2020, Malaysia has adopted the concept of National Blue Ocean Strategy (NBOS) in their five-year strategies of The Eleventh Malaysia Plan, 2016-2020. The Eleventh Malaysia Plan was embedding the Blue Ocean Strategy's tools and frameworks to formulate high-impact and low-cost national strategies that were able to be rapidly executed [16]. Throughout the plan, a theme of "anchoring growth on people" which has six strategic thrusts with six game changers was capsulated. One of the thrust is on improving the wellbeing for all Malaysian, focusing on one of the aspiration's focus area (Focus Area-B), which is providing adequate, quality, and affordable housing to poor, low, and middle income households. Additionally, this aspiration was also considering management and regular standard maintenance of public housing (in Strategy B3) [17].

In Malaysia, basically, most of house accommodations are divided into various categories which are terrace or link house, detached house or bungalows, semi-detached house, long house, flats and apartments, condominiums and shop house [17,18]. In the development of house, there are several parties involved during the construction and after the completion of the house (either from the public sector or the private sector). The key stakeholders are the Ministry of Housing and Local Government (KPKT) with several local authorities, project manager, consultant, contractors, manufacturers and suppliers, and house buyers [20]. Between these parties, there are business agreements in the form of contracts to complete the work in the project, such as; design, engineering, construction, management, and maintenance [20,21]. Meanwhile, private association representing all private housing developers across the Peninsular Malaysia known as Real Estate and Housing Developers' Association Malaysia (REHDA) is recognized as the leading 
representative body for private property developers, which being involved primarily in advocacy and governance [23].

\section{House components}

Structure is a complex system which usually made up from a number of frames or members which bears the dead load and live load. Whilst, a frame or members may consist of several components, and might also need a number of sub-components $[7,23,24]$. The same can be viewed towards a house, which generally needs a collection of components and sub-components. Primarily, structure of house needs several members, which are foundation, column, beam, slab, and truss [26]. Then, to encapsulate all members in becoming envelope-type of structure, floor, wall and roof are constructed and jointed together [26]. Basically, general building works are divided into four different components: structural, architectural, mechanical and electrical (M \& E), and external works [27].

Furthermore, in order to view house components in a more comprehensible manner, indepth literature reviews were conducted to identify house components based on written manuscripts, published sources from all over the world, and Malaysian house components catalogue. Along the way, the research employed a mapping system to outline the major house components which can be assessed using sense perceptions (i.e. vision, hear, touch, smell) since house owner became the concern throughout the research. Lending a support from the works of Kariya et al. [26], the move involved multi-layered thematic analysis as a document analysis tool to collect, filter, and analysed the information based on the research needs [26]. Therefore, Table 1 shows the list of major house components that are available to house owner which are related to Malaysia's environment, and their associated indigenous manufacturers and suppliers of each component, where later on will serve as part of purposive respondents in subsequent stages of research exploration. As can be seen, the main house components consist of twelve (12) main components, namely; staircase, door, window, floor, wall, ceiling, roof and awning, house fittings and fixtures, mechanical and electrical fittings, main gate and fencing, window and door grill, and apron and perimeter drain (citations for each component are shown in Table 1). However, generally they have their own sub-components which at the end will contribute in forming the main components itself. These house components later on become a basis to identify the factors that affect life expectancy of the components and further suggest average life expectancy for each generic house components.

\section{Life expectancy (LE)}

There are a handful number of sources and guidelines on the life expectancy of different house components around the globe. These include the published guideline in 2006 from National Association of Home Builders (NAHB), along with Bank of America titled "Study of Life Expectancy of Home Components" based on manufacturers, trade associations, and product researchers [9]. According to the definition from $\mathrm{Ngo}$ et al. in their article on Establishment of Standards in Property Maintenance - A Pilot Study in Kuala Lumpur, the life expectancy of house component can be defined as the years of life remaining of the components before they break, damage, need further maintenance or need replacement [40]. Their expectancy of life is statistically in the range of number of year's remains of the components starting from their first installation or first built of the components until their last functional usability. The ages between $10-12$ years appears to be the point of the building's life when wear and tear of the building fabric is increasingly visible, where major repairs and refurbishment become necessary to keep the building economically 
competitive [40]. In considering the life expectancy of building, three maintenance strategies are taken which are development, implementation, and management [41].

Table 1. House components (minus sub-components) according to sense perception assessment which related to Malaysia's environment.

\begin{tabular}{|c|c|c|}
\hline Component & $\begin{array}{c}\text { Sense } \\
\text { perception }\end{array}$ & References \\
\hline Staircase & Vision & $\begin{array}{l}\text { Authors: [9], [28], [29], Manufacturers/suppliers: Reliance Home Sdn. Bhd., } \\
\text { Wira Sky Steel Sdn. Bhd., Supercool Creative Culture Sdn. Bhd., COD } \\
\text { Marketing Sdn. Bhd., Weng Hing Stainless Steel Sdn. Bhd., Wira, Wrought } \\
\text { Iron \& Stainless Steel Sdn. Bhd., Solid Glass \& Metal Industries Sdn. Bhd. }\end{array}$ \\
\hline Door & $\begin{array}{l}\text { Vision } \\
\text { Touch } \\
\text { Hear }\end{array}$ & $\begin{array}{l}\text { Authors: [7,9,27-30], Manufacturers/suppliers: Amax Lifestyle Product Sdn. } \\
\text { Bhd., Golden Best, Reliance Home Sdn. Bhd., Space Kete Sdn. Bhd., THC } \\
\text { Metal Engineering Sdn. Bhd., Tropicale Window \& Door Sdn. Bhd., Delux } \\
\text { Stainless Steel Sdn. Bhd., Wira Wrought Iron \& Stainless Steel Sdn. Bhd., Ga } \\
\text { Hing Trading Sdn. Bhd., Honglee Group (M) Sdn. Bhd., Solid Glass \& Meta } \\
\text { Industries Sdn. Bhd., Vin Art Building Materials Sdn. Bhd. }\end{array}$ \\
\hline Window & $\begin{array}{l}\text { Vision } \\
\text { Touch } \\
\text { Hear }\end{array}$ & $\begin{array}{l}\text { Authors: }[25,27-29,31-33], \text { Manufacturers/suppliers: Amax Lifestyle } \\
\text { Product Sdn. Bhd., Breezway Window \& Door Marketing Sdn. Bhd., } \\
\text { Reliance Home Sdn. Bhd., Space Kete Sdn. Bhd., Wira Wrought Iron \& } \\
\text { Stainless Steel Sdn. Bhd., Honglee Group (M) Sdn. Bhd., Solid Glass \& } \\
\text { Metal Industries Sdn. Bhd. }\end{array}$ \\
\hline Floor & $\begin{array}{l}\text { Vision } \\
\text { Touch } \\
\text { Hear }\end{array}$ & $\begin{array}{l}\text { Authors: }[7,9,25,28-36], \text { Manufacturers/suppliers: Orion Contract Sdn. Bhd., } \\
\text { Trocellen S.E.A Sdn. Bhd., Bellezza Ceramiche Sdn Bhd., Decasa Marbles } \\
\text { Sdn. Bhd., Gold Rich Stoneworks Sdn. Bhd., Basis Supreme Sdn. Bhd., Coco } \\
\text { Vinyl Flooring, Continental Aces Sdn. Bhd., Excel Floor Sdn. Bhd., Floor } \\
\text { Depot, Hoss Marketing Sdn. Bhd., I Vanquish Marketing Sdn Bhd, Inova } \\
\text { Resources Sdn. Bhd., Lumber Mart Sdn. Bhd., Netwood, Sugawa Lonwood } \\
\text { Sdn. Bhd., Swoods Sdn. Bhd. }\end{array}$ \\
\hline Wall & $\begin{array}{l}\text { Vision } \\
\text { Touch } \\
\text { Hear } \\
\text { Smell }\end{array}$ & $\begin{array}{l}\text { Authors: [7,8,25,27-31,34], Manufacturers/suppliers: Elegant Haus Wal } \\
\text { Coverings, Lamex Décor (M) Sdn Bhd., Metro Furnishing Sdn Bhd., Nippon } \\
\text { Paint, Orion Contract Sdn Bhd, Thinkerbell Design Solution Sdn Bhd, } \\
\text { Bellezza Ceramiche Sdn Bhd, Decasa Marbles Sdn Bhd, Gold Rich } \\
\text { Stoneworks Sdn Bhd. }\end{array}$ \\
\hline Ceiling & Vision & $\begin{array}{l}\text { Authors: [25,29,34,36] Manufacturers/suppliers: Teng Plaster Ceiling \& } \\
\text { Renovation, Ting Fung Plasterceil Sdn Bhd. }\end{array}$ \\
\hline Roof & Vision & $\begin{array}{l}\text { Authors: [8,9,25,28,30-33,35-37], Manufacturers/suppliers: The Cascade } \\
\text { Team, Wira Sky Steel Sdn. Bhd., De Skylight Roofing Sdn Bhd, Delux } \\
\text { Structural Works sdn Bhd, Monier Malaysia Sdn Bhd, Supercool Creative } \\
\text { Culture Sdn Bhd, COD Marketing Sdn Bhd, Delux Stainless steel Sdn Bhd, } \\
\text { Solid Glass \& Metal Industries Sdn Bhd, Vin Art Building Materials Sdn } \\
\text { Bhd. }\end{array}$ \\
\hline $\begin{array}{l}\text { House } \\
\text { fittings \& } \\
\text { fixtures }\end{array}$ & $\begin{array}{l}\text { Vision } \\
\text { Touch }\end{array}$ & $\begin{array}{l}\text { Authors: }[9,25,28,29] \text {, Manufacturers/suppliers: Reliance Home Sdn. Bhd., } \\
\text { Decasa Marbles Sdn Bhd, Gold Rich Stoneworks Sdn Bhd, Bathcare } \\
\text { Marketing Sdn Bhd, Duravit \& Hansgrohe, Ga Hing Trading Sdn Bhd, Kosa } \\
\text { Malaysia Sdn Bhd, Lg Global (VTO Bath), Molecq Sdn Bhd, Solid Glass \& } \\
\text { Metal Industries Sdn Bhd, The Ultimate Bath Gallery. }\end{array}$ \\
\hline M\&E fittings & $\begin{array}{l}\text { Vision } \\
\text { Touch }\end{array}$ & Authors: $[9,25,28,29,38]$ \\
\hline $\begin{array}{l}\text { Main gate \& } \\
\text { fencing }\end{array}$ & $\begin{array}{l}\text { Vision } \\
\text { Touch }\end{array}$ & $\begin{array}{l}\text { Authors: [28,29,38], Manufacturers/suppliers: Wira Sky Steel Sdn. Bhd., } \\
\text { Supercool Creative Culture Sdn Bhd, B.T. Engineering Sdn Bhd, COD } \\
\text { Marketing Sdn Bhd, Delux Stainless steel Sdn Bhd, Weng Hing Stainless } \\
\text { Steel Sdn Bhd, Wira Wrought Iron \& Stainless Steel Sdn. Bhd., Honglee } \\
\text { Group (M) Sdn Bhd. }\end{array}$ \\
\hline $\begin{array}{c}\text { Door \& } \\
\text { window grill }\end{array}$ & $\begin{array}{l}\text { Vision } \\
\text { Touch }\end{array}$ & $\begin{array}{l}\text { Authors: [29], Manufacturers/suppliers: Wira Sky Steel Sdn. Bhd., B.T } \\
\text { Engineering Sdn Bhd, C.S. Alloy Design (M) Sdn Bhd, Weng Hing Stainless } \\
\text { Steel Sdn Bhd (2016), Honglee Group (M) Sdn Bhd. }\end{array}$ \\
\hline $\begin{array}{l}\text { Drain \& } \\
\text { perimeter } \\
\text { drain }\end{array}$ & Vision & $\begin{array}{l}\text { Author: [29], Manufacturers/suppliers: Hume Concrete Sdn. Bhd., E-Rete } \\
\text { (Malaya) Sdn. Bhd., Oka Corporation Bhd., Lau Tat Sdn. Bhd., Tekun } \\
\text { Concrete Manufacturer, }\end{array}$ \\
\hline
\end{tabular}


A maintenance strategy is being developed for each building that takes into consideration for its priority, life expectancy, condition, and the surrounding environment. Maintenance and improvement strategies are related to three broad bands of life expectancy which are short life (0-5 years), medium life (5-15 years) and long life (15 years and above)[40].

A study from National Association of Home Builders (NAHB) has concluded that, there are several factors that could affect the life expectancy of house components. These are qualities of products and materials, the quality of their installation (including workmanship and tools), their level of maintenance and replacement, exposure to weather and climatic conditions, and intensity of use. Besides, there are some components to remain functional but become outdated because of changing of styles and technology, or because of product improvements [9]. Therefore, it is understandable that life expectancy of house components may vary in every country depending on the previous affecting factors of their life span. Thus, for that reason, the identification of life expectancy for house components is indeed needed to encapsulate those factors in order to envisage LE holistically.

\section{Identifying process of house components' life expectancy}

In conducting a research, basically, there are eight (8) types of research design that will be selected by researchers based on their research purpose; which are experimental and quasiexperimental designs, correlational designs, survey designs, grounded theory designs, ethnographic designs, narrative research designs, mixed method design, and action research designs [42]. This study is much likely embarked on pragmatic moves, where mixed method design consisting of qualitative and quantitative inquiry is considered.

Learning from past studies conducted by Kariya et al. [26], Mohammad et al. [43], and several other researchers from developed countries (e.g. UK and US), the first phase of the research (i.e. identifying house components) were adopting qualitative approach through appropriate document analysis (i.e. literature reviews) in order to answer the "what?" question before moving on to the next phase of research. Literatures are derived mostly from books, journals, and legitimate documents which provide established lists of house components, life expectancy's factors, and other valuable information such as suggested average life expectancy. A multi-layered thematic process is embedded in order to capture associated research's key points whilst encapsulate prior identified research's scopes. These several layers of themes were purposely produced in order to collect, filter, and analyse related information [43], particularly on sense perceptions and local housing environment. Then, collected data will be directed to successive phase of research exploration.

Subsequently, due to the nature of research topic that requires further insight on LE's phenomenon and at the same time necessitates large pool of data, the second phase (i.e. life expectancy identification) are embedding both qualitative and quantitative approaches respectively. Qualitative method through purposive semi-structured interviews towards relevant construction practitioners were deemed paramount in order to shed light on certain variables' clusters (i.e. house components, life expectancy's factor, range of life expectancy) and doubled as validation purpose. Meanwhile, the succeeding quantitative method through questionnaire surveys were dedicated to capture purposive respondents' perceptions (i.e. significant factor of life expectancy and life expectancy) and to generalise appropriate outcomes. In order to identify life expectancy's factors, house components were divided into several generic types before differentiation of materials and finishing follows. According to preliminary observations, types of components dictate different life expectancies, and the circumstance are further varied consistent with material selection and finishing applied. On the other hand, life expectancy itself covers an average life span of components and their average periodic maintenance, respectively. After that, quality 
measure will be imposed at the end of the research before finalising any findings. The following figure (see Fig. 1) shows the thematic processes in a glance.

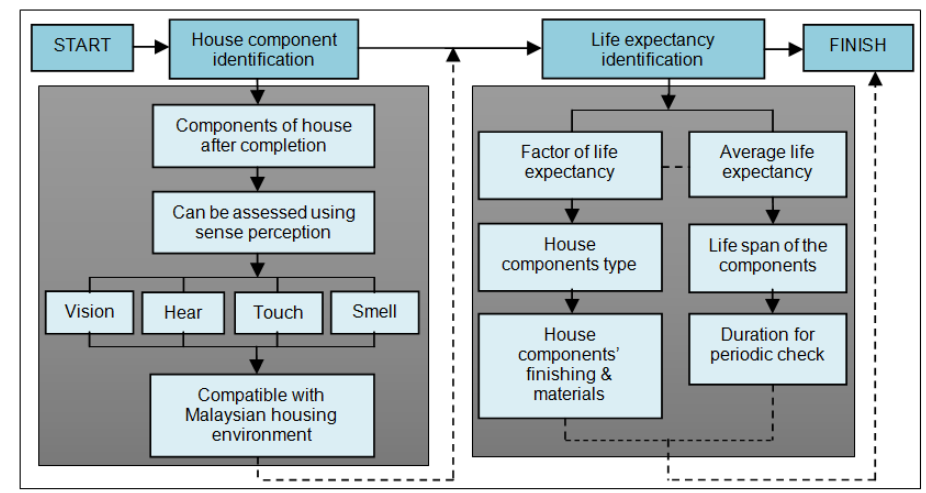

Fig. 1. Multi-layered thematic process.

\section{Conclusion and way forward}

This paper serves as the basis for preliminary explorations aiming at identifying literatures and references that will benefit the authors in conducting subsequent moves. It is understood that house maintenance is an important facet of management for house owners. Late awareness on house components' defects can be dangerous to the occupants of the house itself. Generally, the ostensive damages on the house components usually occur after the Defect Liability Period (DLP) in which any cost of repairing the damages is borne by the house buyers themselves. Due to that, a study on life expectancy of house components is deemed as needed, in which the findings will become a term of reference for house buyers. Aside from assisting for periodic maintenance in preserving house components from further critical damages on behalf of house owners, the positive outcome may spill over towards other services entity such as the insurance's sector. The research is adopting a mixed-methodology, where the excerpt of research phases can be perused in Figure 1.

In a nutshell, in order to identify house component's life expectancy, several clusters of variable need to be concerned together such as house components (including their materials and finishing), factors that affect the life expectancy, and the average life expectancy itself (including their lifespan and periodic maintenance period). Besides, past studies conducted should be referred to in order to grasp the pragmatic moves taken by them. For instance, in developed country (e.g. UK, US), studies on life expectancy was already conducted, however their findings may differ due to localised housing environment such as climate condition and types of house components. Thus, the authors' mooted house components as listed on Table 1 are able to be assessed using sense perception (i.e. vision, touch, hear, smell), and its compatibility with Malaysia's environment has been identified. Protected and closely covered components such as house foundation and beams, and climate incompatibility such as roof chimney and fireplace were excluded in the list. Therefore, preliminary finding shows that there are twelve (12) main components of house including staircase, door, window, floor, wall, ceiling, roof, house fittings and fixtures, mechanical and electrical fittings, main gate and fencing, door and window grill, and exterior house drain. Along with their appropriate sub-components, the research is optimistically ready for successive explorations. To sum up, it can be concluded that successive tools (i.e. multilayered thematic process) to analyse related literatures are required in order to avoid any deviation from the research aim and scope. This preliminary action aptly benefited the 
exploration of central phenomenon in hand, and at the same time capturing apposite pragmatic moves taken by past researchers for subsequent betterment in this research.

The authors would like to convey sincere gratitude to Universiti Tun Hussein Onn Malaysia (UTHM) for sponsoring this paper and research through their in-house research grant.

\section{References}

[1] Valuation and Property Services Department, Property market report, Ministry of Finance Malaysia, Kuala Lumpur, (2015)

[2] A. Suffian, Some common maintenance problems and building defects: Our experiences, Procedia Enginering, 54, 101-108, (2013)

[3] C. Liew, N.A. Haron, Factors influencing the rise of house price in Klang Valley, Int. J. of Research in Engineering and Technology, 2(10), 261-272, (2013)

[4] A.S. Ali, S.N. Kamaruzzaman, R. Sulaiman, Y.C. Peng, Factors affecting housing maintenance cost in Malaysia, J. Facility Management, 8(4), 285-298, (2010)

[5] Buildings Department Hong Kong, Building maintenance guidebook, Hong Kong, (2002)

[6] B. Kayan, Maintaining old building during post gazzeted period - case study: Kuala Lumpur, the Malaysian surveyor, J. Inst. Surv., 40.1, 15-22, (2006)

[7] R. Coleman, Residential construction for new home covered by home warranty insurance in British Columbia, Government of British Columbia, Canada, (2014)

[8] Department of Communities and Local Government, A decent home: Definition and guidance for implementation, London, (2006)

[9] Economics Group of NAHB, Study of life expectancy of home components, US Department of Housing and Urban Development, USA, (2007)

[10] Worldometers, Malaysia Population, Dadax, (2016), Retrieved on October, 2016 from

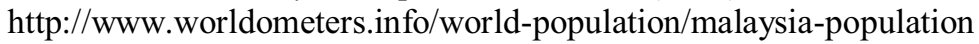

[11]Department of Statistics Malaysia, Department of Statistics Malaysia press release, Kuala Lumpur, (2016)

[12] S.S. Hock, The population of Malaysia, Second edi., Institute of Southeast Asian Studies, Singapore, (2007)

[13]Department of Statistics Malaysia, Department of Statistics Malaysia press release quarterly construction statistics, Fourth Quarter 2015, Malaysia, ( 2016)

[14] Investopia, Top 25 developed and developing countries, (2016), Retrieved on November 22, 2016 from http://www.investopedia.com/updates/top-developingcountries

[15] Kementerian Kesejahteraan Bandar Perumahan dan Kerajaan Tempatan, KPKT statistics 2014, Malaysia, (2014)

[16]Blue Ocean Strategy, Blue ocean strategy for national development, (2016), Retrieved on October 11, 2016 from https://www.blueoceanstrategy.com/blue-ocean-strategy-fornational-development

[17]Economic Planning Unit, Rancangan Malaysia Kesebelas (Eleventh Malaysia Plan): 2016-2020, Percetakan Nasional Malaysia Berhad, Malaysia, (2015)

[18] Y.H. Lee, Homebuyers' requirements for housing development within districts in Selangor, Master Thesis, Universiti Teknologi Malaysia, Malaysia, (2006)

[19] S.A.Q.S.A. Karim, The significance of owner participation for a successful detached housing development in Malaysia, PhD Thesis, Queensland Univesity of Technology, Queensland, Australia, (2013) 
[20]D.J. Tan, F.E.M. Ghazali, Critical success factors for Malaysian contractors in international construction projects, Int. Conf. on Engineering, Project and Production Management, Singapore, 127-138, (2011)

[21]U.K. Zolkafli, N. Zakaria, H. Salleh, The comparative study of international standard form of building contract (FIDIC conditions of contracts for construction - The new red book 1999) and Malaysian's Standard Form of Building Cotract (PWD 203A), Int. Engineering Education Conf., (2011)

[22]H. Singh, Construction contracts: An overview, The Ingenieur, 6-20, (2005)

[23]Real Estate and Housing Developers' Association Malaysia, Official Website of REHDA: Real Estate and Housing Developers' Association Malaysia (REHDA), (2000), Retrieved on March 21, 2016 from http://rehda.com

[24]Canadian Association of Home and Property Inspectors, National Standards of Practice, Canada, (2012)

[25]Carson Dunlop and Associates Ltd, Inspection a house: A Guide for buyers, owners and renovators, Third eds., Dearborn Trade Publishing, USA, (2004)

[26]N. Kariya, Z. Yaakob, M.N.M. Sairi, H. Mohammad, S.K. Yaman, N.H. Abas, Investigation of generic house components and their practical ways to be assessed by house buyers during defect liability period (DLP) in Malaysia, Int. Congress on Technology, Engineering and Science, Kuala Lumpur, (2016)

[27] Construction Industry Development Board Malaysia, Construction industry standard CIS 7:2014 quality assessment system for building construction works, Kuala Lumpur, (2014)

[28]H. John, C. Geoff, The technology of building defects, Taylor and Francis, (1997)

[29] International Association of Certified Home Inspectors, InterNACHI'S estimated life expectancy chart for Florida homes, (2006), Retrieved on December 4, 2015 from http://www.nachi.org/florida-life-expectancy.htm

[30] Construction Industry Development Boar, CIS 7:2006 Quality assessment system for building construction work, Malaysia, (2006)

[31] M.S. Richard, H. Dave, Home buyer's checklist, McGraw, New York, (1993)

[32]B.A. Richardson, Defects and deterioration in buildings, $2^{\text {nd }}$ eds. Spon Press, New York, (2001)

[33] Home Builders Association of Northwest Indiana, How long will it last? The life expectancy of your home's components, Northwest Indiana, (2015)

[34] G. Peter, Building surveys, Butterworth-Heinemann, Italy, (2006)

[35]B. Jay, Building construction inspection: A guide for architects, Wiley, USA, (1991)

[36]D. James, A.N. Edward, Building surveys and reports, Wiley, New York, (2011)

[37]M.D. Spada, The home inspection book: A guide for professionals, South-Western Educational Publishing, Ohio, (2002)

[38] Jabatan kerja Raya Malaysia, JKR standard specification, Malaysia, (2014)

[39] American Society of Home Inspectors, The standard of practice for home inspection and the code of ethics for the home inspection profession, USA, (2014)

[40]M. Ngo, Establishment of standards in property maintenance - A pilot study in Kuala Lumpur, Building Miantenance and Modernisation Worlwide, Singapore, (1990)

[41]R.A. Bates, Maintenance strategy - A Hong Kong prospective, Proc. of the Int. Symposium on Property Maintenance Management and Modernisation, Logman Singapore, 28-38, (1990)

[42]J.W. Creswell, Educational research: Planning, conducting, and evaluating quantitative and qualitative research, Pearson Education, USA, (2012)

[43]H. Mohammad, S.K. Yaman, F. Hassan, Z. Ismail, Z. Determining the technical competencies of construction managers in the Malaysia's construction industry, MATEC Web of Conf., 47, 04021, (2016) 